\title{
BIOLOGICAL FEATURES ON EPIBIOSIS OF Amphibalanus improvisus (CIRRIPEDIA) ON Macrobrachium acanthurus (DECAPODA)*
}

\author{
Cristiane Maria Rocha Farrapeira ${ }^{1 * *}$ and Tereza Cristina dos Santos Calado ${ }^{2}$ \\ ${ }^{1}$ Universidade Federal Rural de Pernambuco - UFRPE \\ Departamento de Biologia \\ (Rua Dom Manoel de Medeiros, s/nº, 52-171-900 Recife, PE, Brasil) \\ ${ }^{2}$ Universidade Federal de Alagoas - UFAL \\ Laboratório Integrado de Ciências do Mar e Naturais \\ (Rua Aristeu de Andrade, 452, 57051-090 Maceió, AL, Brasil) \\ **c.farrapeira@db.ufrpe.br
}

\begin{abstract}
A B S T R A C T
This study aimed to describe the epibiosis of barnacles Amphibalanus improvisus on eight adult Macrobrachium acanthurus males from the Mundaú Lagoon, state of Alagoas, Brazil. The number of epibiont barnacles varied from 247 to 1,544 specimens per prawn; these were distributed predominantly on the cephalothorax and pereiopods, but also on the abdomen and other appendices. Although some were already reproducing, most barnacles had been recruited recently or were still sexually immature; this suggests recent host arrival in that estuarine environment. Despite the fact that other barnacles occur in this region, A. improvisus is the only species reported as an epibiont on Macrobrachium acanthurus; this was also the first record of epibiosis on this host. The occurrence of innumerable specimens in the pereiopods' articulations and the almost complete covering of the carapace of some prawns (which also increased their weight) suggest that $A$. improvisus is adapted to fixate this kind of biogenic substrate and that the relationship between the two species biologically damages the basibiont.
\end{abstract}

\section{RESUMO}

O objetivo deste trabalho foi relatar a epibiose de cirrípedes Amphibalanus improvisus em oito camarões machos adultos da espécie Macrobrachium acanthurus provenientes da Laguna Mundaú, Alagoas, Brasil. O número de cirrípedes epibiontes variou desde 247 até 1.544 espécimes por camarão, distribuídos predominantemente no cefalotórax e pereiópodos, mas presentes também no abdome e demais apêndices. A grande maioria dos cirrípedes era recém-recrutada ou ainda estava sexualmente imatura, embora de alguns estivessem já em reprodução, sugerindo a chegada recente de seu hospedeiro no ambiente estuarino. Apesar de ocorrem outros cirrípedes na região, A. improvisus foi à única espécie relatada como epibionte em Macrobrachium acanthurus e isto se constituiu o primeiro registro de epibiose de Amphibalanus improvisus A ocorrência de inúmeros espécimes nas articulações dos pereiópodos e o recobrimento quase total da carapaça de alguns camarões (incrementando peso aos mesmos) indicam que a espécie epibionte está adaptada à fixação neste substrato biogênico e que a relação entre estas duas espécies traz prejuízos biológicos ao basibionte.

Descriptors: Barnacle, Prawn, Estuary, Epibiosis, Commensalism.

Descritores: Cirrípede, Camarão, Estuário, Epibiose, Comensalismo. 


\section{INTRODUCTION}

Macrobrachium acanthurus (Wiegmann, 1836), locally known as the cinnamon prawn or "pitu", inhabits fresh and brackish waters of coastal rivers and bays freely connected to the sea, and is distributed from North Carolina to southern Brazil (COELHO and RAMOS-PORTO, 1985; ABELE and KIM, 1986; VALENTI et al., 1989; SIGNORET and BRAILOVSKY, 2004). This edible prawn is the basis of small fisheries exploited by several human communities close to estuaries, and is an economically important natural resource. Due to its size, high fertility and fecundity rates, easy maintenance and reproduction in laboratory conditions, and good acceptance on the consumer market, it is also considered a species with cultivation potential on a commercial scale (CHOUDHURY, 1970; NEW, 1995; RAMOS-PORTO, 1980; COELHO and RAMOSPORTO, 1985; SOUSA and CALADO, 1998; QUADROS et al., 2004).

In the state of Alagoas, northeastern Brazil, M. acanthurus is found in the shallow waters of the Mundaú/Manguaba lagoon system, where it is a dominant species in number and biomass and occurs throughout the year at most stations (COELHO et al., 1990; TEIXEIRA and SÁ, 1998; SOUSA et al., 2000;
CALADO and SOUSA, 2003). It is one of the most exploited prawns and is usually sold in urban centers.

The finding of some male specimens severely fouled by barnacles in the Mundaú Lagoon during a bioindicator project has received much attention; according to local vendors, these specimens have completely lost their commercial value. This study aimed, therefore, to record and investigate the relationship between the prawn Macrobrachium acanthurus and its epibiont barnacle species and to quantitatively describe the abundance and spatial distribution of ectosymbionts.

\section{Material and Methods}

The Mundaú Lagoon (with an area of 24 $\mathrm{km}^{2}$ ), located in the neighborhood of Pilar (a town near Maceió, Alagoas, Northeast Brazil), is part of the Mundaú/Manguaba complex (9³6'S - 9 $45^{\circ} \mathrm{S}$, $35^{\circ} 41^{\prime} \mathrm{W}-35^{\circ} 55^{\prime} \mathrm{W}$ ), which in turn receives its main freshwater input from the Mundaú River. It is connected to the Atlantic Ocean and the Manguaba Lagoon by a network of channels (OLIVEIRA and KJERFVE, 1993; NORMANDE, 2000) (Fig. 1). Air temperature varies from an average of $30.1^{\circ} \mathrm{C}$ in the dry season to $20.8^{\circ} \mathrm{C}$ in the wet season, when salinity is around zero (MACÊDO et al., 1987; NORMANDE, 2000).

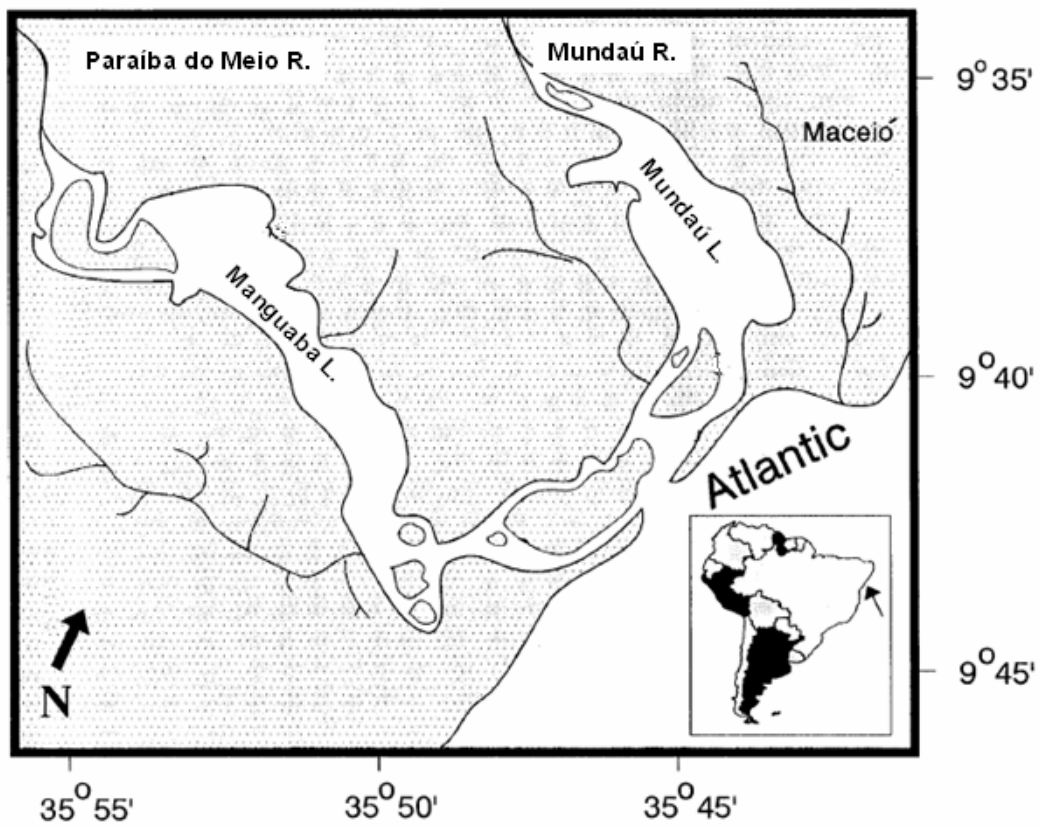

Fig. 1. Mundaú/Manguaba complex, Alagoas, Northeast Brazil. 
As part of another study, which aimed to analyze the quantities of heavy metals and the ecotoxicology of invertebrates in the Mundaú/Manguaba complex, 21 prawns were collected by a fisherman in February 2008 near the margins of the Mundaú lagoon. This fisherman used artisanal wooden traps baited with cassava. Of the total, eight male prawns hosting macro-epibiont barnacles were brought to the laboratory for closer examination (the remaining prawns were used for the ecotoxicology and heavy metal analysis). A stereomicroscope and optical microscopes were used to identify and count the number of epibiont individuals. The presence of other symbiotic species (colonies) was also reported and their position on the prawns registered.

The prawns' carapace length (rostrum to telson) and barnacles' carinorostral diameter (carina to rostrum plates) were measured using a caliper $(\mathrm{mm})$. The epibiont barnacles were counted directly on the carapaces using a stereomicroscope and insoluble paint/dye to mark the individuals counted. The counting was repeated three times and when the data disagreed an average number was taken. The number of specimens on each area of the prawn is presented and, for statistical analyses, also grouped according to their occurrence on two main regions and three groups of appendages. The two regions were the cephalothorax carapace (including rostrum) and the abdomen (including telson), while the three groups of appendages included the cephalic (including the ocular peduncles and the ocular orbit itself); thoracic and abdominal appendages. The barnacles on the ventral region were also counted. Statistical analyses (Friedman and the Wilcoxon signed-rank tests) were carried out to relate the various anatomical units of the crab to the epibionts. Digital images of organisms were registered using a Sony Cyber-shot DSC-W35 camera, some images also being obtained through a dissecting microscope lens. Voucher prawn specimens and their symbiotic species have been deposited in the respective taxonomic Crustacea (Universidade Federal de Alagoas - CC07773) and Cirripedia collections (Universidade Federal Rural de Pernambuco DBUFRPE n. 1132).

\section{REsUlts}

The barnacle A. improvisus was present on all the male prawn specimens (mean carapace length of $14.98 \pm 0.10 \mathrm{~cm})$. In addition to the barnacle Amphibalanus improvisus (Darwin, 1854), the main epibiont species, two other unidentified commensals were found: a Vesiculariidae bryozoan and a Sertulariidae hydrozoan. The Vesiculariidae bryozoan colonies covered the cuticle of a single prawn (specimen 8), where it formed a network of thin stolons fixed on the carapace like armor intercalated within the barnacle's shells They also fouled the entire cephalothoracic carapace (including the rostrum and basal articles of antennas), three abdominal somites, four pereiopods, two pleopods, and the uropods, as well as the ventral cephalothoracic and abdominal areas, between the appendices (Fig. 2). The hydrozoans consisted of short dead stalks without hydrants and were found on two prawns (specimens 5 and 6), solely on the second and third pereiopods (Fig. $3)$.

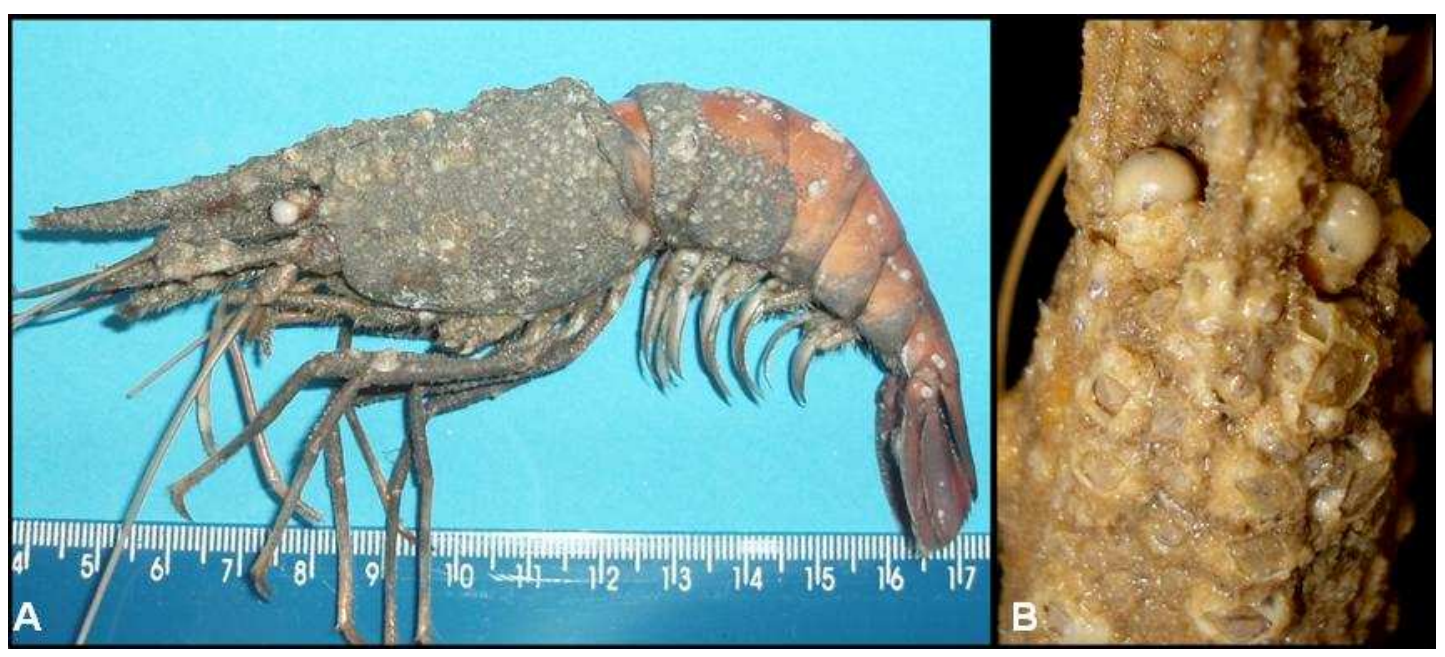

Fig. 2. Prawn (specimen 8) with cuticle recovered by the barnacle Amphibalanus improvisus and bryozoans. a. Lateral view; $\mathrm{b}$. dorsal view of the cephalothorax and rostrum. 


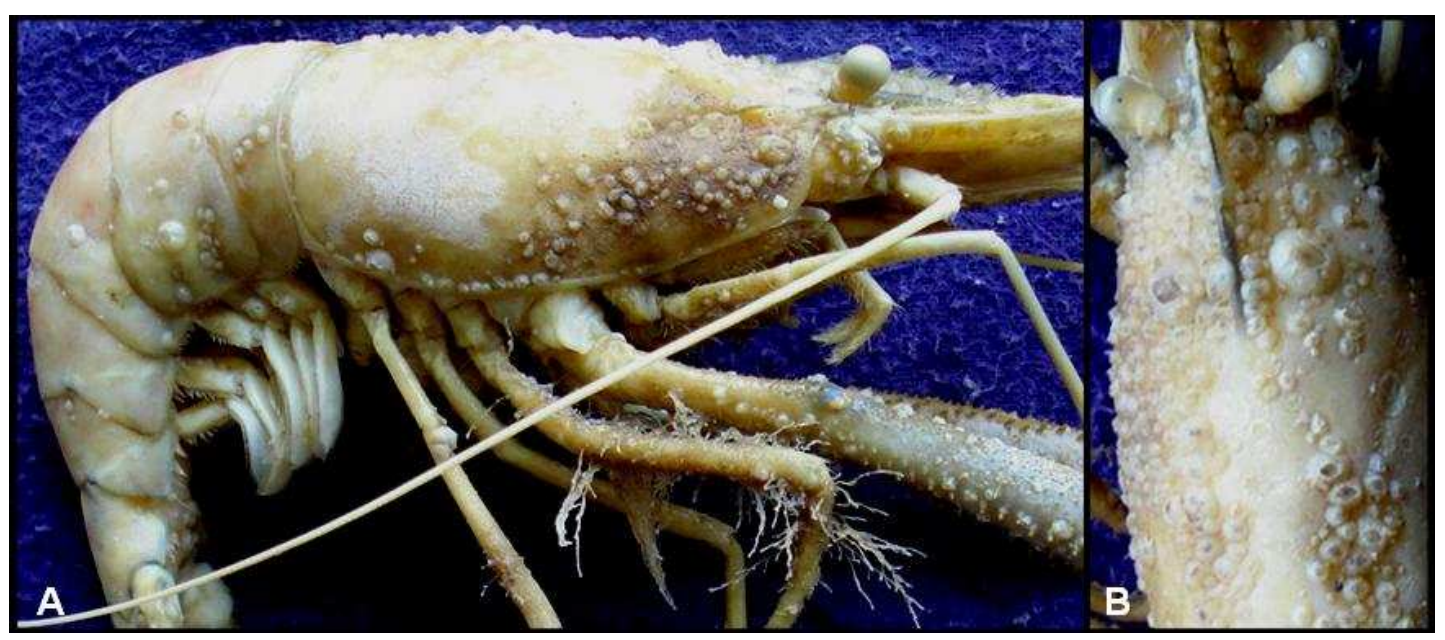

Fig. 3. Prawn (specimen 6) with the barnacle Amphibalanus improvisus and the hydrozoans. a. overall view, showing the hydrozoans on the third pereiopod; b. dorsal view of the cephalothorax and rostrum.

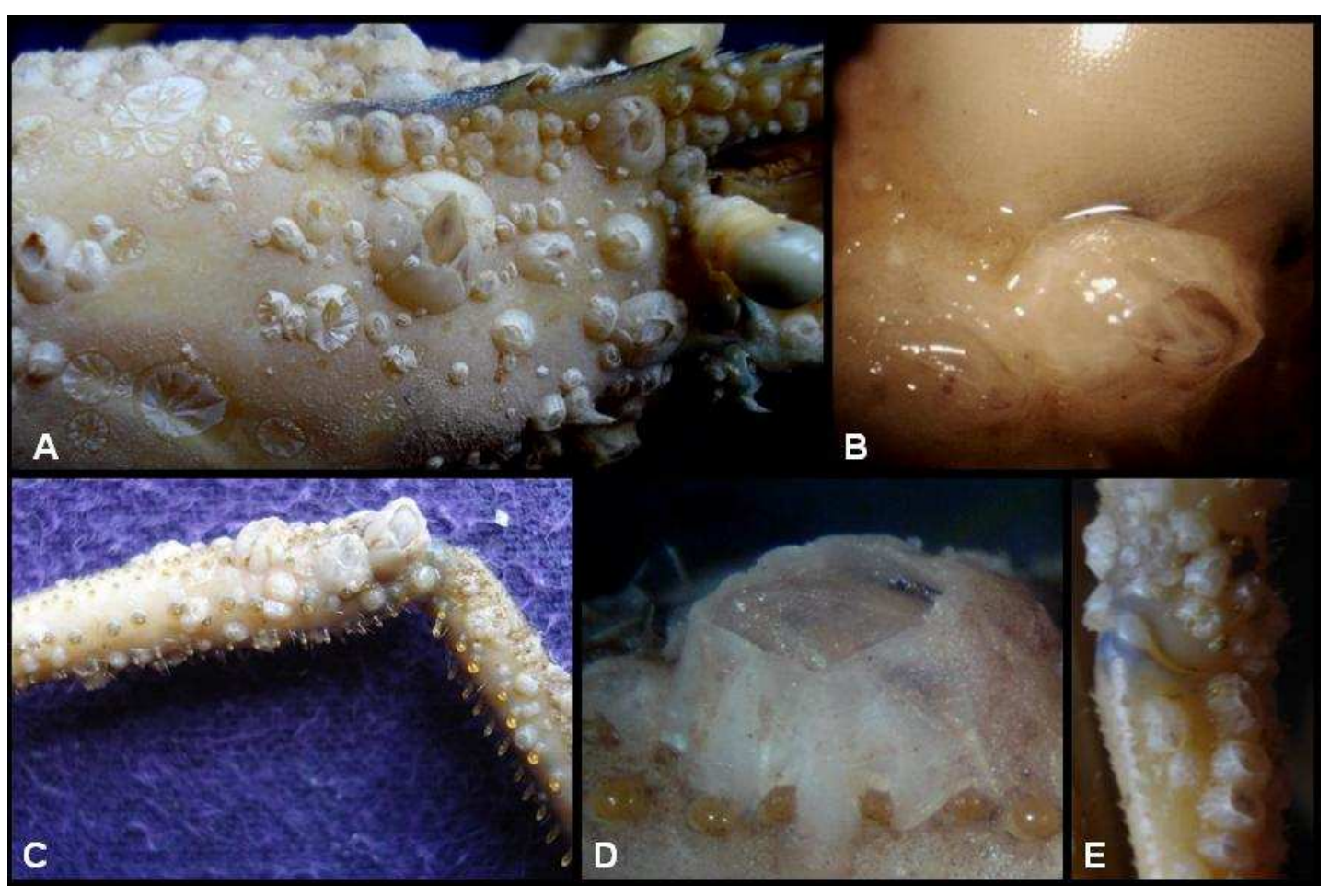

Fig. 4. Prawn with barnacles Amphibalanus improvisus. a. adults and recent recruits on the cephalothorax cuticle, showing some scars of the calcareous basis of removed barnacles; b. two barnacles on the peduncle and ocular orbit; c. recovering of barnacles on the prawn's second pereiopod; d. details of the basal margin of the barnacle shell with ecomorphosis caused by the spines; e. hardened articulation of the prawn's second pereiopod.

The number of barnacles attached to each prawn ranged from 247 large individuals (specimen 1) to 1,544 smaller ones (specimen 8 ). Table 1 lists the number of barnacles present on each of the different body regions and appendages. In most thoracic and abdominal appendices, barnacles occurred mainly on 
the coxopodit and basipodit. Few barnacles were attached laterally onto the pleura or on the mid-dorsal line of the abdominal segments. The barnacles' settling areas included the ocular orbit and peduncle (Fig. 3b, $4 \mathrm{~b}$ ), the antenna's flagellum, the sexual appendage, and several furrows of the articulations (Fig. 4c, 4e). Ecomorphosis was observed for the barnacles that grew among the spines and setae of the second pereiopods; in this case, the basal margin of their shell had unusual hollows (Fig. 4d).

As regards the various body regions, the cephalothoracic carapace was the main settlement area, with the dorsal carina surface (dorsum) as the main site (Fig. 3b, 4a). Among the body appendages, barnacles preferred the thoracic ones (especially the pereiopods) and were more numerous on the second pereiopod (Fig. 4c) for those specimens that still had it (740 animals on specimen 2's pair) (Table 1). When comparing barnacle counts across these two regions and the three types of appendages, significant differences were only found between the cephalothoracic carapace and the abdominal appendages (Friedman test, df $\mathrm{D}=21.5 ; \mathrm{P}<0.05$ ) and between the thoracic and abdominal appendages (Friedman test, df $\mathrm{D}=19 ; \mathrm{P}<0.05$ ). A significant difference was also observed among the barnacles' settlement patterns - far more were attached to the cephalothoracic carapace than to the abdominal somites (Wilcoxon signed-rank test, $\mathrm{P}=0.0357$ ).

Most of these barnacles were recent recruits or still sexually immature, although some specimens were adults (Fig. 4a), were in reproduction, had well developed gonads, and were even incubating eggs. The carinorostral diameter of most young barnacles was of $1.7 \pm 1.1 \mathrm{~mm}$. The diameter of the largest specimens examined was of $4.1 \pm 2.1 \mathrm{~mm}$ (measurements of the mature specimens, settled mainly on the surface of the dorsal carina).

\section{Discussion}

It was not a surprise to find three epibiont species on prawn surfaces. The lack of available hard and stable substrate is often a limiting factor for fouling organisms, especially in estuarine areas with muddy bottoms like the Mundaú Lagoon. The calcified carapaces of decapod crustaceans appear to be one of the few suitable mobile habitats for epibiont attachment in this type of inhospitable, soft sediment bottom, as pointed out by Ross (1983) and Gili et al. (1993). Furthermore, despite its relatively short lifespan due to moulting (shedding of the crab's exoskeleton), many organisms (protozoans, algae, barnacles, bryozoans, hydrozoans, bivalves) use this substratum as an alternative hard substrata (ABELLÓ and CORBERA, 1996).

Table 1. Total number of barnacles found attached to specific body regions and appendices ("app" - grouped data) on specimens (spc.) of Macrobrachium acanthurus. Prawn's carapace length ("prawn") and average barnacle's carinorostral diameter ("barnacles") are given in millimeters (mm).

\begin{tabular}{|c|c|c|c|c|c|c|c|c|}
\hline & spc. 1 & spc. 2 & spc. 3 & spc. 4 & spc. $5^{\mathrm{H}}$ & spc. $6^{\mathrm{H}}$ & spc. 7 & spc. $8^{B}$ \\
\hline Prawn & 139.2 & 150.6 & 152.2 & 161.8 & 133.2 & 151.3 & 147.8 & 162.1 \\
\hline $\begin{array}{l}\text { Barnacles } \\
\text { cephalothorax }\end{array}$ & $\begin{array}{l}1.7 \\
28\end{array}$ & $\begin{array}{l}3.8 \\
27\end{array}$ & $\begin{array}{l}2.7 \\
234\end{array}$ & $\begin{array}{c}\mathbf{2 . 3} \\
317\end{array}$ & $\begin{array}{l}\mathbf{5 . 2} \\
289\end{array}$ & $\begin{array}{l}4.7 \\
249\end{array}$ & $\begin{array}{l}2.1 \\
418\end{array}$ & $\begin{array}{l}2.2 \\
652\end{array}$ \\
\hline abdomen & 75 & 194 & 65 & 48 & 37 & 73 & 53 & 320 \\
\hline cephalic app. & 28 & 38 & 97 & 71 & 63 & 93 & 149 & 216 \\
\hline thoracic app. & $95 \#$ & 22 & $31 \#$ & $81 \#$ & 734 & 740 & 691 & $180 \#$ \\
\hline abdominal app. & 21 & 36 & 11 & 20 & 20 & 5 & 38 & 176 \\
\hline TOTAL & 247 & 317 & 438 & 537 & 1143 & 1160 & 1349 & 1544 \\
\hline
\end{tabular}

${ }^{\mathrm{H}}$ specimens also with hydroids

${ }^{B}$ specimen also with bryozoans

\# second pereiopod only until basipodit article

Several studies have reported the barnacle Amphibalanus improvisus as an epibiont organism. Dawson (1957) found it on the white shrimp Penaeus setiferus (Linnaeus, 1767) of the inshore waters of Mississippi and South Carolina; Eldred (1962) recorded it attached to the exoskeletons of the rock shrimp Sicyonia dorsalis from the Tortugas shrimping grounds, where some also hosted unidentified hydroids; and Giri and Wicksten (2002) collected the fouled peppermint shrimp Lysmata wurdemanni 
(Gibbes, 1850) in Texas. As regards the barnacleshrimp relationship, all these authors also observed that the carapace's dorsolateral surface was the main area of barnacle settlement. Amphibalanus improvisus has been also recorded as an episymbiont on other vagile crustaceans, such as the portunids Callinectes danae Smith, 1869 and C. larvatus Ordway, 1863 (FARRAPEIRA, 2006); the crabs Hemigrapsus sanguineus (De Haan, 1853) (McDERMOTT, 2007), Libinia spinosa Milne Edwards 1834, Neohelice (Chasmagnathus) granulata (Dana, 1851), and Platyxanthus crenulatus A. Milne-Edwards, 1879 (SPIVAK, 2003); and the crayfishes Astacus leptodactylus (Eschscholtz, 1823) (LAMANOVA, 1970) and Pacifastacus trowbridgii (Stimpson, 1857) (COHEN, 1995). It has also been recorded on gorgonians, mollusks, and other barnacles (SILVABRUM and MARTINS, 1996; FARRAPEIRA, 2006, 2008). This is the first record of Amphibalanus improvisus on Macrobrachium acanthurus.

The location of the main barnacle aggregations is not casual, as defense mechanisms against epibionts would be expected if the disadvantages suffered by the host outweighed the benefits (BECKER, 1996). Antifouling strategies such as grooming are partial adaptations to the need to keep the cuticle free of fouling organisms. In caridean species observed preening the body, one of the two pairs of chelipeds is characteristically involved in grooming, as well as its long antennae. Pereiopods used in preening are usually the most slender of the two pairs and bear dense tufts of serrate or multiscaled setae and interdigitating stout setae on the tips of the chelal fingers (BAUER, 1978). In the case of Macrobrachium males - which have unusually enlarged second chelae - these are used in agonistic interactions and predation (GRAVE et al., 2008)

Particular features of epibiosis can provide useful correlative information on the biological and behavioral characteristics of the host (ABELLÓ and CORBERA, 1996; KEY et al., 1996; 1999). There are several considerations that should be borne in mind regarding the relationship between barnacles and prawns. Macrobrachium acanthurus lives preferentially in fresh water and occasionally migrates to brackish waters (COELHO and RAMOS-PORTO, 1985), despite being considered a hyperosmotic regulator in salinities between 0 and 20 (SIGNORET and BRAILOVSKY, 2004). Teixeira and Sá (1998), for instance, have reported that it prefers the fresher waters in the Mundaú/Manguaba lagoonal complex; thus, according to those authors, it only swims into the lagoon proper between July and October, and then only to places where the salinity is less than 5 . The migration of adults to the estuary occurs during the reproductive season - spring and summer (JALIHAL et al., 1993; BOND-BUCKUP and BUCKUP, 1999;
MEJÍA-ORTÍZ et al., 2001). According to Boschi (1974), most species of this genus lay their eggs in brackish water, and adults and larvae need the salinity to complete the reproductive cycle.

The prawns' migratory behavior to the estuarine areas and the fact that it stops for considerable periods of time to perform grooming and cleaning activities (BAUER, 1975) possibly allowed for barnacle larvae to settle on their exoskeleton. Amphibalanus improvisus has previously been recorded in the low salinity area of the Mundaú/Manguaba lagoonal complex (CORREIA, 1998; CALADO and SOUSA, 2003) and has low salinity acclimation (as low as 1-2) (NEWMAN, 1967; FOSTER, 1970; KENNEDY and DICOSIMO, 1983). Its metamorphosis is completed within 8-16 h after permanent attachment (GLENNER and HOEG, 1993).

The short cycle of the barnacle species must also be highlighted, as it is a crucial factor for animals that live on such temporary substrates. Although the frequent molting of caridean prawns does remove all fouling, there might be periods in some species' life cycles when the molting rate is low enough to allow for extensive fouling (e.g., when females are carrying embryos) (FELGENHAUER and SCHRAM, 1979). According to these authors, the normal physiology of prawns is continuously involved in the successive stages of the molting cycle. However, this can be interrupted periodically by gonad maturation, which coincides with the period of migration into the estuary. Since fouling can occur only during interecdysal periods, the barnacles must have developed between the previous molting event and the moment of capture. Dawson (1957) also observed this fact by looking at the time A. improvisus appeared on the penaeid shrimp Penaeus setiferus, when fouling by maturing barnacles was probably confined to this period of reduced molting frequency.

The degree of epibiosis is another aspect to be considered about this symbiotic relationship. The body design of carideans and other natantian decapods consists of a set of adaptations for swimming, particularly the subcylindrical and generally smooth cephalothorax, the flattened antennae scales (that serve as horizontal rudders for control during the escape response), and the long, laterally compressed rostrum that acts as a stabilizing keel (BAUER, 1978). The rugosity of the barnacle shells results in many disadvantages due to the higher energy cost required for movement. Furthermore, the added weight of the attached barnacles on the heavily encrusted prawn and the overlap of the larger barnacles on the body segments undoubtedly interfere with the prawns' natural movement and acceleration and, thus, make it more susceptible to predation (ELDRED, 1962; WAHL, 1989). Fernandez-Leborans and Gabilondo (2005) report that the presence of epibionts on 
Liocarcinus depurator (Linnaeus, 1758) and Pilumnus hirtellus (Linnaeus, 1761) negatively impacts the crab, as the added weight and possible impairment of mobility due to changes in the body's hydrodynamic equilibrium can hinder appendage movement.

Anything preventing movement between segments will interfere with the appendages' locomotory and feeding movements and with body's postural changes; this will thus restrict mobility and interfere with swimming. In this study, several barnacle specimens were found growing on pereiopod articulations, covering sensitive organs (eyes, antennae), and even on the sexual appendage. According to Felgenhauer and Schram (1979), this kind of fouling may hinder locomotion or inhibit sensory reception, depending upon the location and intensity of the infestation. Normal fluid flow within the animal may also become impaired, including loss of chemoreception capacity. The occurrence of numerous specimens on pereiopod articulations and the almost complete covering of some prawns' carapace (in addition to the added weight) indicates that the epibiont barnacle species are adapted for settling on this biogenic substratum. Additionally, the consequent biological damage caused to the basibiont suggests that the relationship between these two species is not simply one of commensalism.

\section{ACKNOWLEDGMENTS}

The authors are grateful to Liliane Tonial and Carlos de Carvalho Veiga who gave us the fouled prawn specimens collected during their project the purpose of which was to assess the impact of pollutants from sugarcane monocultures in the estuaries and coastal waters of Alagoas (Marine Sciences Program - POCALMAR, a bilateral agreement between Brazil and Germany). Special thanks also go to Débora Barbosa, for her valuable help in the statistical analyses, to Andrea Steiner for helping with the English version, and to the anonymous reviewers for their comments.

\section{REFERENCES}

ABELE, L. G.; KIM, W. The decapod crustaceans of the Panama Canal. Washington: Smithsonian Institution Press, 1989. $60 \mathrm{p}$.

ABELLÓ, P.; CORBERA, J. Epibiont bryozoans (Bryozoa, Ctenostomatida) of the crab Goneplax rhomboids (Brachyura, Goneplacidae) off the Ebro delta (western Mediterranean). Misc. Zool., v. 19, p. 43-52, 1996.

BAUER, R. T. Grooming behavior and morphology of the caridean shrimps Pandalus danae Stimpson (Decapoda: Natantia: Pandalidae). Zool. J. Linn. Soc., v. 56, n. 1, p. 45-71, 1975.
BAUER, R. T. Antifouling adaptations of caridean shrimps: Cleaning of the antennal flagellum and general body grooming. Mar. Biol., v. 49, n. 1, p. 69-82, 1978.

BECKER, K. Epibionts on carapaces of some malacostracans from the Gulf of Thailand. J. Crustac. Biol., v. 16, n. 1, p. $92-104,1996$

BOND-BUCKUP, G.; BUCKUP, L. Os Palaemonidae de águas continentais do Brasil meridional (Crustacea, Decapoda). Rev. Bras. Biol., v. 49, n. 4, p. 883-896, 1989.

BOND-BUCKUP, G.; BUCKUP, L. Caridea (pitus, camarões de água doce e marinhos). In: BUCKUP, L.; BONDBUCKUP, G. Os crustáceos do Rio Grande do Sul. Porto Alegre: Ed. Universidade/UFRGS, 1999. p. 300318.

BOSCHI, E. E. Biología de los crustáceos cultivables en América Latina. Carpas, v. 6, p. 1-24, 1974.

CALADO, T. C. S.; SOUSA, E. C. Crustáceos do complexo estuarino-lagunar Mundaú/Manguaba - Alagoas. Maceió: FAPEAL, 2003. 116 p.

CHOUDHURY, P. C. Complete larval development of the Palaemonidae shrimp Macrobrachium acanthurus (Wiegmann, 1836) reared in the laboratory. Crustaceana, v. 18, n. 2, p. 113-132, 1970.

COELHO, P. A.; RAMOS-PORTO, M. Camarões de água doce do Brasil: Distribuição geográfica. Rev. Bras. Zool., S. Paulo, v. 2, n. 6, p. 405-410, 1985.

COElHO, P. A., RAMOS-PORTO, M.; MELO, G. A. S. Crustáceos decápodas do Estado de Alagoas. An. Soc. Nordest. Zool., v. 3, p. 21-34, 1990.

COHEN, A. N.; CARLTON, J. T. Biological study. Nonindigenous aquatic species in a United States estuary: A case study of the biological invasions of the San Francisco Bay and Delta. Washington: National Sea Grant Program, 1995. 79 p.

CORREIA, M. D. Fauna associada a troncos de madeira no Complexo Estuarino-Lagunar Mundaú/Manguaba, Alagoas, Brasil. Bol. Estud. Ciênc. Mar, n. 10, p. 45-64, 1998.

DAWSON, C. E. Balanus fouling on shrimp. Science, v. 126, p. $1068,1957$.

ELDRED, B. The attachment of the barnacle Balanus amphitrite niveus Darwin and other fouling organisms to the rock shrimp Sicyonia dorsalis Kingsley. Crustaceana, v. 3, n. 3, p. 203-206, 1962.

FARRAPEIRA, C. M. R. Barnacles (Cirripedia Balanomorpha) of the estuarine region of Recife, Pernambuco, Brazil. Trop. Oceanogr., v. 34, n. 2, p. 100-119, 2006

FARRAPEIRA, C. M. R. Cirripedia Balanomorpha en el estuario del río Paripe (Isla de Itamaracá-PernambucoBrasil). Biota Neotr., v. 8, n. 3, p. 31-39, 2008.

FELGENHAUER, B. E.; SCHRAM, F. R. The functional morphology of the grooming appendages of Palaemonetes kadiakensis Rathbun, 1902. Fieldiana, Zool., n. 2, p. 1-17, 1979.

FERNANDEZ-LEBORANS, G.; GABILONDO, R. Invertebrate and protozoan epibionts on the velvet swimming crab Liocarcinus puber (Linnaeus, 1767) from Scotland. Acta Zool., v. 89, p. 1-17, 2008.

FOSTER, B. A. Responses and acclimation to salinity in the adults of some balanomorph barnacles. Philos. Trans. R. Soc. Lond., v. 256, n. B810, p. 377-400, 1970. 
GILI, J. M., ABELLÓ, P.; VILLANUEVA, R. Epibionts and intermoult duration in the crab Bathynectes piperitus. Mar. Ecol. Progr. Ser., v. 98, p. 107-113, 1993.

GIRI, T.; WICKSTEN, M. K. Fouling of the caridean shrimp, Lysmata wurdemanni (Gibbes, 1850) by the barnacle, Balanus improvisus Darwin, 1854 and other epibionts. Crustaceana, v. 74, n. 11, p. 1305-1314, 2002.

GLENNER, H.; HOEG, J. T. Scanning electron microscopy of metamorphosis in four species of barnacles (Cirripedia Thoracica Balanomorpha). Mar. Biol., v. 117, n. 3, p. 431-438, 1993.

GRAVE, S.; CAI, Y.; ANKER, A. Global diversity of shrimps (Crustacea: Decapoda: Caridea) in freshwater. In: BALIAN, E. V.; LÉVÊQUE, C.; SEGERS, H.; MARTENS, K. (Eds.). Developments in Hydrobiology. 198. Freshwater animals diversity assessment. Berlin: Springer Netherlands, 2008. p. 287-293.

JALIHAL, D. R.; SANKOLLI, K. N.; SHENOY, S. Evolution of larval developmental patterns and the process of freshwaterization in the prawn genus Macrobrachium (Bate, 1868) (Decapoda, Palaemonidae). Crustaceana, v. 65, n. 3, p. 365-376, 1993.

KENNEDY, V. S.; DICOSIMO, J. Subtidal distribution of barnacles Cirripedia Balanidae in Chesapeake Bay, Maryland, USA. Estuaries, v. 6, n. 2, p. 95-101, 1983.

KEY JR., M.; JEFFRIES, W. B.; VORIS, H. K.; YANG, C. M. Epizoic bryozoans, horseshoe crabs and other mobile benthic substrates. Bull. Mar. Sci., v. 58, n. 2, p. 368384, 1996.

KEY JR., M. M..; WINSTON, J. E.; VOLPE, J. W.; JEFFRIES, W. B.; VORIS, H. K. Bryozoan fouling of the blue crab Callinectes sapidus at Beaufort, North Carolina. Bull. Mar. Sci., v. 64, n. 3, p. 513- 533, 1999.

LAMANOVA, A. I. Attachment by zebra mussels and acorn barnacles on crayfish. Hydrobiol. J., v. 6, n. 6, p. 89-91, 1970.

MACÊDO, S. J.; COSTA, K. M. P.; BARROS, J. B. P. Variação dos parâmetros ambientais da Lagoa Mundaú, Maceió AL e sua influência sobre o ciclo biológico laguna. Bol. Estud. Ciênc. Mar, n. 6, p. 9-35, 1987.

McDERMOTT, J. J. Ectosymbionts of the non-indigenous Asian shore crab, Hemigrapsus sanguineus (Decapoda: Varunidae), in the western north Atlantic, and a search for its parasites. J. Nat. Hist., v. 41, n. 7, p. 2379-2396, 2007.

MEJÍA-ORTÍZ, L. S. M.; ALVAREZ, F.; ROMÁN, R.; VICCON-PALE, J. A. Fecundity and distribution of freshwater prawns of the genus Macrobrachium in the Huitzilapan river, Veracruz, México. Crustaceana, v. 74, n. 1, p. 69-77, 2001.

NEW, M. B. Status of freshwater farming a review. Aquac. Res., v. 26, p. 1-54, 1995.

NEWMAN, W. A. On physiology and behavior of estuarine barnacles. J. Mar. Biol. Ass. India, v. 2, n. 3, p. 10381066, 1967

NORMANDE, E. Meio ambiente estuarino-lagunar: Complexo Mundaú-Manguaba. In: NORMANDE, E. (Org.). Apoio à proteção ambiental em Alagoas: Uma experiência de cooperação técnica. Maceió: Projeto IMA/GTZ, 2000. p. 18-27.

OLIVEIRA, A. M.; KJERFVE, B. Environmental responses of a tropical coastal lagoon system to hydrological variability: Mundaú-Manguaba, Brazil. Estuar.coast. Shelf Sci., v. 37, p. 575-592, 1993.
QUADROS, M. L. A. MACIEL, C.; BASTOS, S.; SAMPAIO, I. Reprodução do camarão canela Macrobrachium acanthurus em condições controladas de laboratório e montagem de um atlas para identificação de estágios larvais. Rev. Cient. UFPA, v. 4, p. 1-11, 2004.

RAMOS-PORTO, M. Estudo ecológico da região de Itamaracá, Pernambuco, Brasil. VII Crustáceos decápodos natantes. Trabs. Inst. Oceanogr. Univ. Fed. Pernambuco, v. 15, p. 277-310, 1980.

ROSS, D. M. Symbiotic relations. In: VERNBERG, F. J.; VERNBERG, W. B. (Ed.). Biology of Crustacea, 7. Behaviour and ecology. New York: Academic Press, 1983. p. 163-212.

SIGNORET, G. P.; BRAILOVSKY, D. S. Adaptive osmotic responses of Macrobrachium acanthurus (Wiegmann) and Macrobrachium carcinus (Linnaeus) (Decapoda, Palaemonidae) from the southern Gulf of Mexico. Crustaceana, v. 77, n. 44, p. 455-465, 2004.

SILVA-BRUM, I. N.; MARTINS, E. M. Epizoísmo de Balanomorpha (Crustacea Cirripedia) em conchas de Mollusca, Baía da Guanabara, RJ, Brasil. Bolm Mus. Nac., n.s., n. 370, p. 1-10, 1996.

SOUSA, E. C.; CALADO, T. C. S. Variação sazonal e proporção sexual da fauna de camarões da região estuarina do Complexo Estuarino-Lagunar Mundaú/Manguaba, Alagoas. Bol. Estud. Ciênc. Mar, n. 10, p. 65-81, 1998.

SOUSA, E. C.; COElHO, P. A.; CALADO, T. C. S. Crustacea Decapoda dos canais da Lagoa Manguaba no complexo estuarino-lagunar Mundaú/Manguaba Alagoas, Brasil. Bol. Estud. Ciênc. Mar, n. 11, p. 165192, 2000.

SPIVAK, E. Los cirripedios litorales (Cirripedia, Thoracica, Balanomorpha) de la región del Río de la Plata y las costas marinas adyacentes. In: PENCHASZADEH, P. E.; BORGES, M. E.; DAMBORENEA, C.; DARRIGRAN, G.; OBENAT, S.; PASTORINO, G.; SCHWINDT, E.; SPIVAK, E. Especies animales bentónicas introducidas, actual o potencialmente invasoras en el sistema del Río de la Plata y la región costera oceánica aledaña del Uruguay y de la Argentina. Buenos Aires: Museo Argentino de Ciencias Naturales "Bernardino Rivadavia", 2003. p. 229-283.

TEIXEIRA, R. L.; SÁ, H. S. Abundância de macrocrustáceos decápodas nas áreas rasas do Complexo Lagunar Mundaú/Manguaba, AL. Rev. Bras. Biol., v. 58, n. 3, p. 393-404, 1998.

VALENTI, W. C.; MELlO, J. T. C.; LOBÃO, V. L. Fecundidade de Macrobrachium acanthurus (Wiegmann, 1836) do Rio Ribeira do Iguape (Crustacea, Decapoda, Palaemonidae). Rev. Bras. Zool., v. 6, n. 1, p. 9-15, 1989.

WHAL, M. Marine epibiosis. I. Fouling and antifouling: some basic aspects. Mar. Ecol. Progr. Ser., v. 58, p. 175-189, 1989.

(Manuscript received 26 February 2009; revised 23 April 2010; accepted 27 April 2010) 